\title{
ANALYSIS OF STUDENTS' AND TEACHERS' RESPONSE OF THE IMPLEMENTATION OF SCIENTIFIC APPROACH WITH PODCAST APP IN TEACHING LISTENING
}

\author{
Desyari Lestari ${ }^{1}$, Cynantia Rachmijati ${ }^{2}$ \\ ${ }^{1,2}$ IKIP Siliwangi \\ ${ }^{1}$ desyarilestari@gmail.com, ${ }^{2}$ cynantia@yandex.com
}

\begin{abstract}
This research is aimed to analyze teachers and students respond in teaching listening skills to the Tenth Grade Students using a scientific approach with learning English podcast applications. This research uses qualitative descriptive, this research is purposed to collect the data both qualitative and quantitative approaches. questionnaires and Interviews. it was done in tenth-grade consist of 21 students in senior high school. The result shows that from two indicators are attention and relevance, from these indicators show that, most of the students respond stated agree in the indicators attention with percentage $471.4 \%$ with the number of frequencies 99 and for indicators relevance most students stated neutral with percentage $228.6 \%$ with total frequency 48 . Also, teacher responses show that students are quite enthusiastic and it is quite an effective way to teach listening. From this research, it can conclude most of the students choose to agree, that the use of podcast make students have a high motivation to the learn, improve retention, easy to understand the material, avoid the wrong concept, it is not boring, and improve listening comprehension, additionally teacher agree that podcast can make students quite enthusiastic during the learning activity.
\end{abstract}

Keywords: Listening skill, podcast, respond, Motivation

\section{INTRODUCTION}

In the teaching-learning English consist of four skills are, listening, speaking, reading and writing that should be mastered in order to communication, it is related with Nan (2018) In English Curriculum Standards for Nine-Year Compulsory Education (2011) stated that the important things that students should enhance extensive language competence for real communication since four language skills are connected and simplify one another in language learning and communication.

According to previous research the four skills can be classified into two types are, the connection between two of the skills and relationship between input and output or in other word between oral and written skills in addtition teaching method of college English speaking, listening, reading or writing has been investigated respectively based on input and output hypothesis (Han, 2016; Guan, 2015; Liu, 2014; Shen, 2012; Zheng, 2010) as cited in (Nan , 2018) All of these skills are important as a fundamental skills to support communication, but the main point in improving general communication ability and language competence is how to develop the listening skill (Hwaider, 2017) cited in (Metruk, 2018). therefore among these skills there are priority that should be mastered first is listening skill.

Talking about that, Listening skills is a complex, active and conscious action in which listeners involved to analyze, interpret and build-up meaning that allows them to comprehend, understand and give a responds orally through their skill to distinguish sounds, knowledge, 
grammatical structures, stress, intonation, and the other linguistic or non-linguistic clues (Rahman, Atmowardoyo, \& Salija, 2018), overall, it may be said as listeners are capable to interpret, comprehend the meaning from what they're listening to then able to give respond orally to communicate is going well, it is the reason how important to enhance listening skills.

But for some reasons students and teacher still faced some difficulties in learning-teaching listening skills, listening is more difficult than reading because during listening activity, they cannot understand the same sentence or even the same word but they can understand when reading (Nan, 2018), also teaching listening skill use technology as media such as video, speaker or recording to make effective teaching-learning skills goes well, in the real implementation sometimes the media problematic or unsupportive facility to teaching listening is still faced by teacher and students (Aryana.S \& Apsari.Y, 2018) with that they did not get enough time to practice listening in the classroom, (Gilakjani \& Ahmadi, 2011) cited in (Metruk, 2018).

Beside that the motivation of students to learn language is considerable impact, In fact, The number of Researchers have examinined that motivation normally identify as important thing in the challenge of learning a foreign language, it is indicates the level of involvement in the learning and the level of mental effort one puts into learning (Means, Jonassen, \& Dwyer, 2004) as cited in (Abdulrahman, 2018), it can be said motivation have important role during students involvement in the learning activity.

Futhermore, In the teaching listening is important to know students motivation during learningteaching activity. Especially how teacher teach listening and make students motivate to learn more about English, there some several way or media, that can make students more enthusiasthic learning English, one of them is podcast, Podcast is one of the instructional media that can be form in application or software version 2.0 envelope. 3 in the form of speech, news, song, story, etc as digital sound, is used to deliver audio recording or broadcasting by using an internet connection (Fachriza \& Gontor, 2020).

Several researchers have been researched podcast to teaching listening skill, Abdulrahman, Basalama, \& Widodo (2018) Some exercises and assignment from podcasts can motivate learners to use their creativity as well as to enhance their listening abilities, according to Ramli \& Kurniawan (2018)in his studies was undertaken to introduce students about podcast taken from British council as an interesting tool of learning activities, it is as follows:

Pre-listening, In this stage where students try to predict the content, it means that giving stimulus before the activity, in pre-listening stage emphasizes helping the students to activate their background knowledge or the information and clarify their expectations and assumptions about the text, While-Listening, in this step the learners hear the input once, for listening main content, and Post-Listening There is an emphasis on helping learners with difficulties and reflecting on performance in the form of writing and reading.

With several facts above, how podcasts can be proven as well in the teaching-learning listening skill, to succeed in achieving learning goals, to find out about that, then it is necessary to know students and teachers' respond, The importance of response in the learning activity is how students can acquire learning outcomes or learning objective during teaching-learning activity. Whereas students responses and learning outcomes as measured for the success of learning (Muhlisin, 2018), this statement is reinforced by the previous research from Febrianti et al., (2015); Suryati (2012); Norsaputra \& Johansyah (2017) as cited in Muhlisin (2018) which 
concluded that "there is a positive relationship between students' response and learning outcomes toward learning process that is used".

In the other hand response related with motivation, it means response has a positive and negative response, positive response indicates have high motivation to know the feeling and negative response indicate low motivation from what they feel this statement is in line with (Muhlisin, 2018) if students are not motivated in learning, it means they have a low response, therefore that students hard to receive messages delivered in the learning process, because Because Learning motivation will enhance learning intensity, and in turn, the learning intensity to interact with basic skills will determine a person's learning accomplishment.

As can be seen, the function to find out students and teachers response toward the implementation podcast application in teaching listening is first to know whether the implementation of podcast app in teaching listening, students able to achieve learning objective, second to get factual overview students motivation during the implementation podcast app in learning listening, and the last to know teachers perception toward students attitude during they learn listening trough podcast app.

Based on the explanation above this research can be formulated in the following questions: What are the responses of teachers and students' in teaching listening skills to the Eleventh Grade Students using a scientific approach with learning English podcast applications?

\section{METHOD}

This research is a qualitative descriptive study, According to Sandelowski, as cited in (Nurmalasari \& Apsari, 2019 ) qualitative descriptive research can be seen as a categorical, as opposed to a non-categorical and more concern in "theoretical" of all of the qualitative approaches to research. This study aims to describe the response of teachers and students' in teaching listening skills to the Tenth Grade Students using a scientific approach with learning English podcast applications. To collect data both qualitative and quantitative approaches have been applied. For quantitative data questionnaires consisting of Sakala Linkert and Interviews were also conducted to find detail information for the study as qualitative data. Subjects of the study will be conducted at XI MIA 2 of MA Multiteknik Asih putera Cimahi, in the academic year 2018/2019, a total of students are 21 students on the. As mentioned previously, two types of instruments were used to find out the answers. These include questionnaires by (Muhlisin, 2018), and to collect qualitative data seven participants were interviewed.

\section{RESULTS AND DISCUSSION}

\section{Results}

Student response data, on the implementation of the podcast application trough the scientific approach, is known from questionnaire distribution. Questionnaire student responses to the use of the application podcast consists of 16 statements developed from indicators as follows.

Table 1. list of questionnaire

\begin{tabular}{clc}
\hline Indicators & Variable & No items \\
\hline 1. Attention & $\begin{array}{l}\text { a. Enjoy Learning (Have a high } \\
\text { motivation to the } \\
\text { learn) }\end{array}$ & 1,2 \\
\hline
\end{tabular}




\begin{tabular}{|c|c|c|}
\hline & b. There is no wrong concept & $4,12,15$ \\
\hline & c. Improve retension & 5,6 \\
\hline & $\begin{array}{l}\text { d. Easy to understand the material of the } \\
\text { course }\end{array}$ & $3,11,16$ \\
\hline \multirow[t]{3}{*}{ 2. Relevance } & a. Boring or not & 7,13 \\
\hline & $\begin{array}{l}\text { b. Reduce the time needed to master the } \\
\text { concept of learning }\end{array}$ & 8,14 \\
\hline & c. Improve listening comprehension & 9,10 \\
\hline
\end{tabular}

Questionnaire response students are given to the eleventh-grade consist of 21 students after implementing the podcast application, aim a description of the data regarding students' responses to the use of the podcast application is to find out how students respond to usage podcast on learning explanation text trough scientific approach. The author calculates the questionnaire responses of students in several ways.

First, the writer recapitulates the results of the student response questionnaire scores have obtained from 21 students by using Ms. Excel, second, the recapitulates questionnaire score data of students' or tabulation data is processed and analyzed by using SPSS, the results are in the form of statistical description output can be seen in the following figure.

Table 2 total score indicator $\mathrm{X}$ and $\mathrm{Y}$

\begin{tabular}{|l|r|r|r|r|r|}
\hline \multicolumn{7}{|c|}{ Descriptive Statistics } \\
\hline & N & Minimum & Maximum & Mean & $\begin{array}{c}\text { Std. } \\
\text { Deviation }\end{array}$ \\
\hline total_X & 21 & 26 & 39 & 34,05 & 3,294 \\
total_y & 21 & 15 & 25 & 20,38 & 3,057 \\
\hline $\begin{array}{l}\text { Valid N } \\
\text { (listwise) }\end{array}$ & 21 & & & & \\
\hline
\end{tabular}

Based on the table above, it can be seen, there are two variables, namely variable $\mathrm{X}$ as an indicator of attention and variable $\mathrm{Y}$ as an indicator of relevance, $\mathrm{N}$ is the number of respondents or students as many as 21 people who fill in the questionnaire, the total score of variable $\mathrm{X}$ (attention) minimum score is 26 , and the maximum score is 39 , while the total score on the variable $\mathrm{Y}$ minimum score is 15 whereas, the maximum score is 25 , the mean on variable $\mathrm{X}$ is 34.5 while the mean on variable $\mathrm{Y}$ is 20.38 and for the standard deviation on variable $\mathrm{X}$ is 3.294 and on variable Y 3, 057.

Third, the authors process data using percentage form. The purpose of the authors describe the results of the questionnaire in the form of a percentage to find out the percentage of each item of each variable, The description of the percentage data for each item statement is as follows. Percentage Data Student Questionnaire for Attention Indicator as variable X consists of enjoy learning, no wrong concept, improve retention and Easy to understand the material of the course. It can be seen as follows. 
Table 3.1. Percentage of each item students response attention indicator

\begin{tabular}{|r|c|c|c|c|c|c|c|c|c|c|c|}
\hline \multicolumn{10}{|c|}{ Persentage of each item students response attention indicator } \\
\hline \multicolumn{2}{|c|}{ NO ITEM } & strongly Disagree & \multicolumn{2}{|c|}{ Disagree } & \multicolumn{2}{c|}{ Neutral } & \multicolumn{2}{c|}{ Agree } & \multicolumn{2}{c|}{ Srongly Agree } \\
\hline$(+)$ & $(-)$ & FREKUENSI & $\%$ & FREKUENSI & $\%$ & FREKUENSI & $\%$ & FREKUENSI & $\%$ & FREKUENSI & $\%$ \\
\hline 1 & & & & 3 & 14,3 & 6 & 28,6 & 12 & 57,1 & & \\
\hline 2 & & & & 3 & 14,3 & 7 & 33,3 & 10 & 47,6 & 1 & 4,8 \\
\hline 3 & & & & 4 & 19,0 & 9 & 42,9 & 8 & 38,1 & & \\
\hline 4 & & & 1 & 4,8 & 4 & 19,0 & 16 & 76,2 & & \\
\hline 5 & & & & & & 9 & 42,9 & 11 & 52,4 & 1 & 4,8 \\
\hline 6 & & & & 3 & 14,3 & 15 & 71,4 & 3 & 14,3 & & \\
\hline & 11 & & & 5 & 23,8 & 10 & 47,6 & 6 & 28,6 & & \\
\hline \multicolumn{2}{|r|}{12} & & & 6 & 28,6 & 9 & 42,9 & 6 & 28,6 & & \\
\hline 15 & & & & 1 & 4,8 & 3 & 14,3 & 13 & 61,9 & 4 & 19,0 \\
\hline 16 & & & & & & 6 & 28,6 & 14 & 66,7 & 1 & 4,8 \\
\hline \multicolumn{2}{|c|}{ TOTAL } & & & 26 & 123,8 & 78 & 371,4 & 99 & 471,4 & 7 & 33,3 \\
\hline
\end{tabular}

Derived from Table 3.1 above, states that students' responses to the use of instructional media with application podcasts trough scientific approach on the attention indicator $(\mathrm{X})$ consist of enjoy learning, no wrong concept, improve retention and Easy to understand the material of the course, which is $123.8 \%$ states disagreed with the number of frequencies $26,15.4 \%$ stated neutral with the number of frequencies $78,471.4 \%$ stated agreed with the number of frequencies 99 and $33.3 \%$ stated strongly agreed with the number of frequencies 7.

Based on the percentage of students respond, most agree that the use of podcast applications in teaching listening trough scientific approach can make students enjoy their learning activity, there is no wrong concept during learning, improve retention and easy to understand the material itself.

Percentage Data Student Questionnaire for Indicator relevance as a variable Y consists of Boring or not, Reduce the time is needed to master the concept of learning and Improve listening comprehension.

Table 3.2. Percentage of each item students response relevance indicator

\begin{tabular}{|c|c|c|c|c|c|c|c|c|c|c|c|}
\hline \multicolumn{9}{|c|}{ Persentage of each item students response relevance indicator } \\
\hline \multicolumn{2}{|c|}{ NO ITEM } & strongly Disagree & \multicolumn{2}{c|}{ Disagree } & \multicolumn{2}{c|}{ Neutral } & \multicolumn{2}{c|}{ Agree } & \multicolumn{2}{c|}{ Srongly Agree } \\
\hline$(+)$ & $(-)$ & FREKUENSI & $\%$ & FREKUENSI & $\%$ & FREKUENSI & $\%$ & FREKUENSI & $\%$ & FREKUENSI & $\%$ \\
\hline 7 & & & & 3 & 14,3 & 7 & 33,3 & 8 & 38,1 & 3 & 14,3 \\
\hline 8 & & & & 4 & 19,0 & 10 & 47,6 & 6 & 28,6 & 1 & 4,8 \\
\hline 9 & & & & 2 & 9,5 & 12 & 57,1 & 6 & 28,6 & 1 & 4,8 \\
\hline 10 & & & & & & 6 & 28,6 & 13 & 61,9 & 2 & 9,5 \\
\hline & 13 & & & 7 & 33,3 & 8 & 38,1 & 6 & 28,6 & & \\
\hline \multicolumn{2}{|c|}{14} & 2 & 9,5 & 11 & 52,4 & 5 & 23,8 & 2 & 9,5 & 1 & 4,8 \\
\hline \multicolumn{2}{|c|}{ TOTAL } & 2 & 9,5 & 27 & 128,6 & 48 & 228,6 & 41 & 195,2 & 8 & 38,1 \\
\hline
\end{tabular}

Drew on table 3.2 above states that student responses to the use of instructional media with application podcasts on the relevance indicator (Y) consist of, Boring or not, Reduce the time needed to master the concept of learning and Improve listening comprehension, which is $9.5 \%$ states strongly disagree with total frequency $2,128.6 \%$ stated disagree with total frequency 27 , $228.6 \%$ stated neutral with total frequency 48 and $195.2 \%$ stated agreed with total of frequencies 41 and $38.1 \%$ stated strongly agreed with the number of frequencies 8 . Based on the percentage of students' responses, mostly still neutral that the use of podcast applications in 
teaching listening, students choose neutral related to Boring or not, Reduce the time needed to master the concept of learning and Improve listening comprehension during a learning activity. But the results of the percentage between neutral and agree are not too far away, some students still confuse to choose to disagree or agree then they choose neutral, but in this study, several students have been interviewed as a data triangulation to complete students responses beside questionnaire. Through this interview sessions can be explained that:

a) Based on the results of the interview, students 'responses to the use of media podcasts through a scientific approach, regarding indicators of relevance related to students' boredom when learning to use podcast media, most students feel not bored, but there are things to consider during learning activity to use podcasts therefore that students do not get bored quickly, there is, podcast topics that are varied and interesting when used in a learning activity that to students do not feel bored with the same topic, and it is better to use podcasts in one material not too often used at each meeting

Does studying with this podcast application media bore you?

"I don't feel bored because it's something new for me, but it depends on the learning"

b) Student responses toward the implementation of podcast media through a scientific approach, regarding indicators of relevance related to Reduce the time is needed to master the concept of learning, most students feel not too fast to understand the material and need a little time to understand the material with the podcast media, due to habits they learn visually through the blackboard, besides that, they need to be accustomed to practicing their listening skill, therefore, they can understand the material more quickly.

During the learning activity to take place using podcast media, does it take long to understand the material?

"At the beginning of the learning meeting using podcasts, I felt, I take a long time to understand the material, then I practiced it and I started to be able to"

c) The interview results, most students feel motivated to learn English through application podcasts, they feel enthusiastic during learning activity and learning English with application podcasts that is something new for them because listening to native people speak and can listen and read simultaneously so easy to understand, this is related to students' responses to attention indicators about enjoy learning.

Are you more motivated to learn to listen by using media podcasts? Want to continue learning? "I am motivated to learn because it is more comfortable, also I can listen and read at the same time"

Teacher responses here to explain the opinion of how the use of media podcasts application can be so effective during learning and teaching activities as well as illustrate the teacher's perception of the use of application podcast media towards students' attitudes during the activity. Through this interview sessions can be explained that:

1) The teacher's opinion regarding the use of the podcast application during a learning activity, it can be said to be quite good because during teaching-learning activity in the pre activities in a brainstorming session before entering into the material to be taught, then entering into the core activities where the material is in the podcast so that it is quite effective for understanding the material, besides when teaching using the podcast media will be better if the way to teach it is more expressive to get the attention of students. 
2) The teacher's perception of students' attitudes during learning activity to use the podcast application is, most students are quite enthusiastic because the media is new in learning activity, then some students have to be reminded that sometimes some students don't like English, or only certain material they like besides that almost students are quite happy during learning activity with podcast application.

\section{Discussion}

In this study about analyzing students 'and teachers' responses to the implementation of podcast application media with a scientific approach to teaching listening, it can be illustrated that podcast application media is an effective enough way to learn listening skills and achieve learning objective that can be proven by students and teacher responses, as stated earlier (2015); Suryati (2012); Norsaputra \& Johansyah (2017) as cited in Muhlisin (2018) there is a relation between response and learning objective itself, talking about learning objective or learning outcomes in every meeting teaching-learning activity should be considered whether students can achieve that or not.

Based on the student responses that can be seen from these two indicators shows that most of the students agree and can be said to be able to achieve the learning objectives seen from the indicator of attention or indicator variable $X$ related to easy to understand the material of the course, there is no wrong concept, enjoy learning and improve retention, most show agreement with the percentage of $471.4 \%$ with the number of frequencies 99 , for example, item question no 16 about easy to understand the material most of the students agree with the percentage of $66.7 \%$ with total frequencies 14 , it means that students can understand the material in the podcast application at the meeting, and one of the learning objectives is students able to understand the material in the podcast.

Also, it was said earlier that Learning motivation will advance desire and ambition to enhance learning objectives (Maya \& Evy, 2014) as cited in (Muhlisin, 2018), which means that high student motivation will influence students to be able to achieve learning objectives, based on the results of interviews and results the percentage of item no 1 on the indicator of attention about enjoy learning with $58.1 \%$ with the number of frequencies 12 most students stated agree that indicated a high motivation to the learn.

Although the relevance indicator or variable Y most of the students answer to neutral with a percentage of $228.6 \%$ with a total frequency of 48 , then the results of the interview as triangulation data to strengthen the response statement to students is the implementation of podcasts during learning activity can be boring or not, from the results of the percentage of students stated neutral, to ensure it, the results of the interview stated that most students agreed that the media application podcast was not boring and whether the implementation of the podcast during learning activity can Reduce the time needed to master the concept of learning, most of the students stated neutral, to ensure it, from the result of interview most of students disagree, that the use of podcast can be Reduced the time is needed to master the concept of learning.

While the teacher's response is to provide an overview of the teacher's perception on student attitudes during learning by using the podcast application which states that, the use of the podcast application during learning makes students feel enthusiastic about learning, this is following previous research from Abdulrahman, Basalama, \& Widodo (2018) Podcasts give positive efforts to enthusiastically respond to teachers so the levels of their learning speed up 
desirably. Some exercises and tasks from podcasts can motivate learners to use their creativity as well as to enhance their listening abilities, it can be seen when the student's enthusiasm during the treatment period using podcast media in the classroom.

\section{CONCLUSION}

Based on these results it can be said that the response of students and teachers to the use of the media application podcast with a scientific approach to teaching listening is quite good because based on the results of the interview and the percentage between two indicators namely the indicator of attention to the variable $\mathrm{X}$ and the indicator of relevance to the variable $\mathrm{Y}$ most students choose to declare agree, that the use of a podcast application with a scientific approach can make students have a high motivation to the learn, improve retention, easy to understand the material, avoid the wrong concept, it is not boring, and improve listening comprehension, However, students do not agree with Reduce the time is needed to master the concept of learning because students are not accustomed to practicing their listening skill and students' learning habits themselves, while teacher responses based on interviews with the use of podcast application media can make students enthusiastic in learning activity and sufficient effective in understanding a material.

\section{ACKNOWLEDGMENTS}

The researchers would like to express our gratitude and acknowledge the funder of the research and publication: PROJECT (Professional Journal of English Education), IKIP Siliwangi.

\section{REFERENCES}

Abdulrahman, T. R. (2018). Ted Talks Video and Students' Listening Skills. The Asian ESP Journal, 14(06), 60-80. https://doi.org/10.34005/lingua.v1i02.190

Abdulrahman, T. R., Basalama, N., \& Widodo, M. R. (2018). The Impact of Podcasts on EFL Students' Listening Comprehension. International Journal of English Linguistics, 8(6), 122. https://doi.org/10.5539/ijel.v8n6p122

Aryana.S \& Apsari.Y. (2018). Analyzing Teacher' s Difficulties. ELTIN, Journal of English Language Teaching in Indonesia, 6(II), 100-106.

Fachriza, A., \& Gontor, U. D. (2020). The Effect of Audio Podcast Application on Guessing Meaning Skill on Teaching Listening Comprehension. 4(1).

Metruk, R. (2018). Extensive Listening Practice of EFL Learners with Authentic English Videos. Teaching English with Technology, 18(4), 3-19. Retrieved from file:///C:/Users/User/Downloads/1541142990wpdm_ARTICLE1.pdf

Muhlisin, A. (2018). Analysis of Students 'Response of The Implementation of RMS ( Rading , Mind Mapping , and Sharing ) Learning Model In Philosophy of Science. 7(1), 13-18.

Nan, C. (2018). Implications of Interrelationship among Four Language Skills for High School English Teaching. 9(2), 418-423.

Rahman, A., Atmowardoyo, H., \& Salija, K. (2018). Podcast Effects on EFL Learners Listening Comprehension. Journal of English Language Teaching, 5(2), 1-10.

Ramli, A. mardila, \& Kurniawan, E. hari. (2018). The Use of Podcast to Improve Students' Listening and Speaking Skills for EFL Learners. 5(2), 1-10. https://doi.org/10.2991/iconelt-17.2018.42 